\title{
HERBICIDE RESISTANCE IN BLACK NIGHTSHADE AND ONEHUNGA WEED
}

\author{
K.C. HARRINGTON ${ }^{1}$, A.J. WARD ${ }^{2}$ and D.M. WELLS ${ }^{3}$ \\ ${ }^{1}$ Massey University, Private Bag 11-222, Palmerston North \\ ${ }^{2}$ Heinz Wattie's Australasia, PO Box 502, Feilding \\ ${ }^{3}$ NZ Sports Turf Institute, PO Box 12-462,Penrose, Auckland \\ Corresponding author: K.Harrington@massey.ac.nz.
}

\begin{abstract}
When black nightshade (Solanum nigrum) plants were poorly controlled by cyanazine in a Manawatu pea crop, seeds were collected from these plants and susceptibility of the resulting seedlings to various herbicides was compared in pot experiments with other black nightshade plants. The biotype was resistant to cyanazine, terbuthylazine, atrazine, prometryn and possibly also terbutryn. No damage occurred even when a 30 -fold increase in the recommended application rate of terbuthylazine was applied. Pot trials were also conducted at Massey University to study the poor control of Onehunga weed (Soliva sessilis) by herbicides noticed in turf at Helensville. This trial showed the Helensville ecotype to be resistant to pyridine herbicides, resulting in no control by clopyralid, triclopyr, picloram/2,4-D and picloram/triclopyr mixtures. Strategies to control both resistant ecotypes are discussed.
\end{abstract}

Keywords: herbicide resistance, black nightshade, Onehunga weed, terbuthylazine, clopyralid.

\section{INTRODUCTION}

In 1999, two potential cases of herbicide resistance in weeds were reported to Massey University. Black nightshade (Solanum nigrum) was not controlled by cyanazine in a pea crop at Rongotea, near Palmerston North. At the Helensville Golf Course, a population of Onehunga weed (Soliva sessilis) which looked different from the normal Onehunga weed was unaffected by a picloram/2,4-D mixture (Tordon 50-D). Fruits of surviving plants from both populations were obtained to investigate whether resistance had developed.

Within New Zealand, there are only seven confirmed cases of herbicide resistance reported in the literature (Bourdot 1996; Harrington \& Hewage 1997), although large numbers have been reported overseas (Heap 2001). Two of the New Zealand cases involve resistance to triazine herbicides, namely fathen (Chenopodium album) and willow weed (Polygonum persicaria)(Bourdot 1996). Biotypes of black nightshade have developed resistance to triazine herbicides in several overseas countries (Zanin \& Lucchin 1990; Heap 2001) so resistance in the Rongotea population was strongly suspected. There are three published cases of weed species developing resistance to phenoxy herbicides in New Zealand, with nodding thistle (Carduus nutans) and slender winged thistle (Carduus pycnocephalus) resistant to 2,4-D (Harrington \& Hewage 1997), and giant buttercup (Ranunculus acris) resistant to the closely related MCPA (Bourdot 1996). However, resistance to pyridine herbicides, such as picloram, has seldom occurred anywhere in the world (Heap 2001), so resistance to the picloram/2,4-D mixture appeared less likely.

This paper reports work to confirm whether resistance occurred in these two populations, and to investigate alternative strategies for controlling these weeds. 
Trial 1

\section{MATERIALS AND METHODS}

Seeds were extracted from the Rongotea black nightshade berries and spread over a bark-based potting mixture in $800 \mathrm{ml}$ pots on 3 April 2000. Other pots were sown the same day with black nightshade seeds taken from plants growing near Massey University in a plot of ground being cropped for the first time in at least 15 years. All pots were kept in a heated glasshouse and kept moist by an automated overhead watering system.

On 16 May 2000, nine rates of terbuthylazine (Gardoprim) ranging logarithmically from $0.09 \mathrm{~kg} / \mathrm{ha}$ to $24 \mathrm{~kg} / \mathrm{ha}$ were applied to these pots. For all three trials reported here, a randomised block design was used with five replicates and untreated controls. Plants were less than $10 \mathrm{~cm}$ high when sprayed, with an average of 7.6 plants per pot, and applications were made with a precision pot sprayer at 315 litres/ha of spray solution. The average air temperature in the glasshouse for the 3 weeks after application was $22^{\circ} \mathrm{C}$ (range $18-31^{\circ} \mathrm{C}$ ). Plant mortality was determined after 22 days by counting the number of live and dead plants in each pot. Chi square analysis was used to compare the two populations.

\section{Trial 2}

The susceptibility of the Rongotea black nightshade population to a wide range of herbicides was compared with that of a black nightshade population from a cropping paddock several kilometres away at Kairanga where no herbicide resistance had been noticed in the past. Seedlings from within commercial pea crops (planted in mid-October) at both sites were transplanted on 20 November 2000 into planter bags $(900 \mathrm{ml})$ in an unheated shadehouse at Massey University. The soil from the original paddocks was used in the planter bags, which was a Kairanga sandy silt loam for both populations. The seedlings were allowed to recover from transplant shock before being sprayed on 6 December 2000 at the 4-6 leaf stage. The treatments (Table 1) were applied by precision pot sprayer at 316 litres/ha. Damage to plants was scored at regular intervals, then all plants were harvested after 10 weeks, weighed and numbers of berries produced were counted.

Trial 3

On 23 March 2000, seeds of the Helensville Onehunga weed population were sown into $700 \mathrm{ml}$ pots containing a peat-based potting mix, which were subsequently kept in a heated glasshouse at Massey University with automated overhead irrigation. A week later, more pots were planted with Onehunga weed seedlings taken from a lawn at Massey University which were at the same growth stage as the Helensville plants. Most pots had 10-20 plants. The plants were occasionally trimmed and left over winter to get well established.

Eight herbicide treatments (Fig. 2) were applied to plants on 19 October 2000 in 286 litres/ha of water, apart from the bentazone and bromofenoxim treatments which were applied in 572 litres/ha of water. The temperature during spraying was $21^{\circ} \mathrm{C}$, and the average temperature over the 7 days after spraying was $22^{\circ} \mathrm{C}$ (range $13-36^{\circ} \mathrm{C}$ ). Damage was scored over subsequent weeks and an analysis of variance was used to compare treatment means.

\section{Trial 1}

\section{RESULTS AND DISCUSSION}

The Rongotea population was significantly less affected $(\mathrm{P}<0.05)$ than the Massey University population by the terbuthylazine at all application rates tested (Fig. 1). Unfortunately there was movement of terbuthylazine from plants treated with high rates on to those with low application rates by water droplet splash from the overhead irrigation, so the mortality of Massey plants at low application rates should be ignored. A rate of $0.25 \mathrm{~kg} / \mathrm{ha}$ terbuthylazine applied to the susceptible Kairanga population in Trial 2 caused no mortality, as would be expected for a rate one third of the 
recommended rate. Distance between plants was increased in Trials 2 and 3 to avoid the problem occurring again.

Despite this problem, almost no plants from the Rongotea population were damaged by any rate of terbuthylazine, showing that resistance to terbuthylazine in this population has developed. The highest rate applied is equivalent to 32 times the recommended application rate of $0.75 \mathrm{~kg} / \mathrm{ha}$ for weed control in pea crops.

Not all plants from the Massey population died at high rates of application, suggesting that the resistance gene was present in some plants. Although the Massey site has probably never been treated with triazine herbicides, it is only $500 \mathrm{~m}$ from the Massey University orchard. Triazine herbicides were discontinued from use in this orchard in the early 1990s after many years of simazine use eventually resulted in poor control of black nightshade. Birds probably transported berries from these plants to the site from where our seeds were collected.

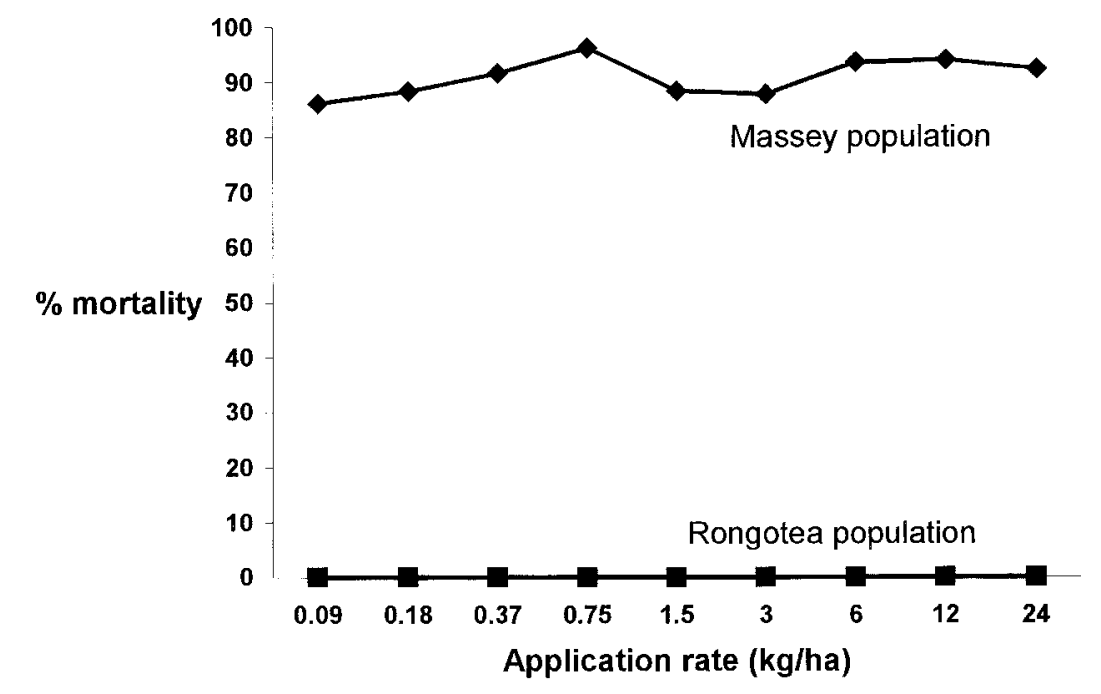

FIGURE 1: Mortality of black nightshade plants from the Rongotea and Massey University populations following treatment with terbuthylazine.

Trial 2

The Rongotea black nightshade population was once again found to be significantly less susceptible to terbuthylazine than the Kairanga population (Table 1). However, cross-resistance was also evident to the other two chlorotriazines tested, namely cyanazine and atrazine. This was not surprising as most cases of chlorotriazine resistance in weeds have resulted in cross-resistance (Heap 2001). Also, cyanazine was the herbicide with which problems were first noticed in the field. Cross-resistance was also evident to the two methylthiotriazines tested, namely prometryn and terbutryn. The terbutryn used in the trial was over 11 years old so gave poor control of the susceptible population, making the resistance difficult to detect. But significant differences were evident 3 weeks after treatment. The cross-resistance to prometryn was more marked.

Negative cross-resistance has been reported for black nightshade where triazine-resistant plants have been shown to be more sensitive than normal to other herbicides such as bentazone 
TABLE 1: The effect of herbicide treatments on potted black nightshade plants from Rongotea and Kairanga at 3, 6 and 10 weeks after treatment (WAT).

\begin{tabular}{|c|c|c|c|c|c|c|c|c|}
\hline \multirow[t]{2}{*}{$\begin{array}{l}\text { Herbicide } \\
\text { (kg ai/ha) }\end{array}$} & \multicolumn{2}{|c|}{$\begin{array}{l}\text { Score }^{1} \\
(3 \mathrm{WAT})\end{array}$} & \multicolumn{2}{|c|}{$\begin{array}{l}\text { Score } \\
(6 \mathrm{WAT})\end{array}$} & \multicolumn{2}{|c|}{$\begin{array}{c}\text { Fresh } \\
\text { weight/pot }(\mathrm{g}) \\
(10 \mathrm{WAT})\end{array}$} & \multicolumn{2}{|c|}{$\begin{array}{l}\text { Berries/pot } \\
\text { (10 WAT) }\end{array}$} \\
\hline & $\begin{array}{l}\text { Rongo- } \\
\text { tea }\end{array}$ & $\begin{array}{l}\text { Kai- } \\
\text { ranga }\end{array}$ & $\begin{array}{c}\text { Rongo- } \\
\text { tea }\end{array}$ & $\begin{array}{l}\text { Kai- } \\
\text { ranga }\end{array}$ & $\begin{array}{c}\text { Rongo- } \\
\text { tea }\end{array}$ & $\begin{array}{l}\text { Kai- } \\
\text { ranga }\end{array}$ & $\begin{array}{l}\text { Rongo- } \\
\text { tea }\end{array}$ & $\begin{array}{l}\text { Kai- } \\
\text { ranga }\end{array}$ \\
\hline terbuthylazine $(0.25)$ & 5) - & 2.2 & - & 0.6 & - & 8.36 & - & 31.4 \\
\hline terbuthylazine (1.0) & 3.4 & 9.6 & 2.8 & 8.8 & 8.71 & 1.36 & 24.4 & 5.0 \\
\hline cyanazine (1.5) & 1.0 & 10.0 & 0.0 & 10.0 & 10.91 & 0.00 & 24.8 & 0.0 \\
\hline atrazine (1.5) & 0.6 & 10.0 & 0.0 & 10.0 & 12.71 & 0.00 & 29.8 & 0.0 \\
\hline prometryn $(0.75)$ & 4.2 & 9.6 & 2.0 & 9.6 & 7.38 & 0.75 & 20.6 & 3.2 \\
\hline terbutryn $(0.35)$ & 0.4 & 4.4 & 0.0 & 2.6 & 10.68 & 7.79 & 28.0 & 26.2 \\
\hline $\begin{array}{l}\text { methabenz- } \\
\text { thiazuron (1.4) }\end{array}$ & 9.4 & 9.0 & 8.6 & 6.4 & 1.39 & 3.91 & 4.8 & 10.6 \\
\hline pendimethalin (2.0) & 7.0 & 5.4 & 7.6 & 7.0 & 3.49 & 23.54 & 2.4 & 8.6 \\
\hline bentazone $(0.96)$ & 8.6 & 8.2 & 6.0 & 5.0 & 3.77 & 4.01 & 7.6 & 13.6 \\
\hline MCPB (1.4) & 8.6 & 6.4 & 8.4 & 4.0 & 1.71 & 4.68 & 2.4 & 6.2 \\
\hline dicamba $(0.3)$ & 9.6 & 9.8 & 8.6 & 7.8 & 0.95 & 0.89 & 2.6 & 2.4 \\
\hline untreated & 0.0 & 0.0 & 0.0 & 0.0 & 11.25 & 12.60 & 29.2 & 39.8 \\
\hline LSD $(\mathrm{P}<0.05)$ & \multicolumn{2}{|c|}{2.4} & \multicolumn{2}{|c|}{3.2} & \multicolumn{2}{|c|}{4.81} & \multicolumn{2}{|c|}{11.8} \\
\hline
\end{tabular}

${ }^{1}$ Scores range from 0 (healthy) to 10 (dead).

(Kutrys et al. 1998). Likewise, resistant biotypes have been found to be less competitive than susceptible plants (Zanin \& Lucchin 1990). The growth differential was noted in both our trials as plants from Rongotea did not grow as aggressively as the other two populations. There was some suggestion of negative cross-resistance in that the Rongotea plants appeared to be more affected by some herbicides, such as MCPB or pendimethalin, than the Kairanga plants. But these differences were generally not significant and may have been caused by the Rongotea plants being slightly smaller than the Kairanga plants at treatment.

Results suggest that for control of triazine-resistant black nightshade in peas, herbicides such as MCPB, bentazone, methabenzthiazuron and pendimethalin can still be used if applied early enough. In maize, dicamba is probably the best option of the herbicides evaluated here.

The Rongotea site has been cropped for many years with peas, maize and sweet corn, and cyanazine was used for weed control in all these crops. The Kairanga site was being cropped for the first time after many years in pasture. Cropping farmers that rely heavily on triazine herbicides for weed control need to reconsider their present crop and herbicide rotations to avoid this resistance from developing. Note however that triazine resistance has developed at the Rongotea site even though most pea crops have also been treated with MCPB each year and sweet corn crops have also had alachlor applied.

Trial 3

Results indicate that not only is the Helensville Onehunga weed population resistant to the 2,4-D/picloram mixture, it is also resistant to clopyralid, triclopyr and the triclopyr/ picloram mixture (Fig. 2). Picloram, triclopyr and clopyralid are all closely related pyridine herbicides (Anderson 1996). While there was almost no noticeable effect on plants sprayed with clopyralid or triclopyr, the higher rate of 2,4-D/picloram did cause some damage. However neither 2,4-D nor triclopyr are normally very effective on Onehunga weed.

The resistance of this population of Onehunga weed to clopyralid and triclopyr/ picloram mixtures presents practical problems as these are two of the more effective 
herbicides for turf weeds. However, alternative herbicides to control the resistant ecotype are available since good control was obtained from the bentazone, bromofenoxim and mecoprop/ioxynil/bromoxynil treatments.

Unlike the black nightshade populations, the herbicide resistant Onehunga weed plants are morphologically different to susceptible plants, with less branched leaflets. This will assist with management of the problem.

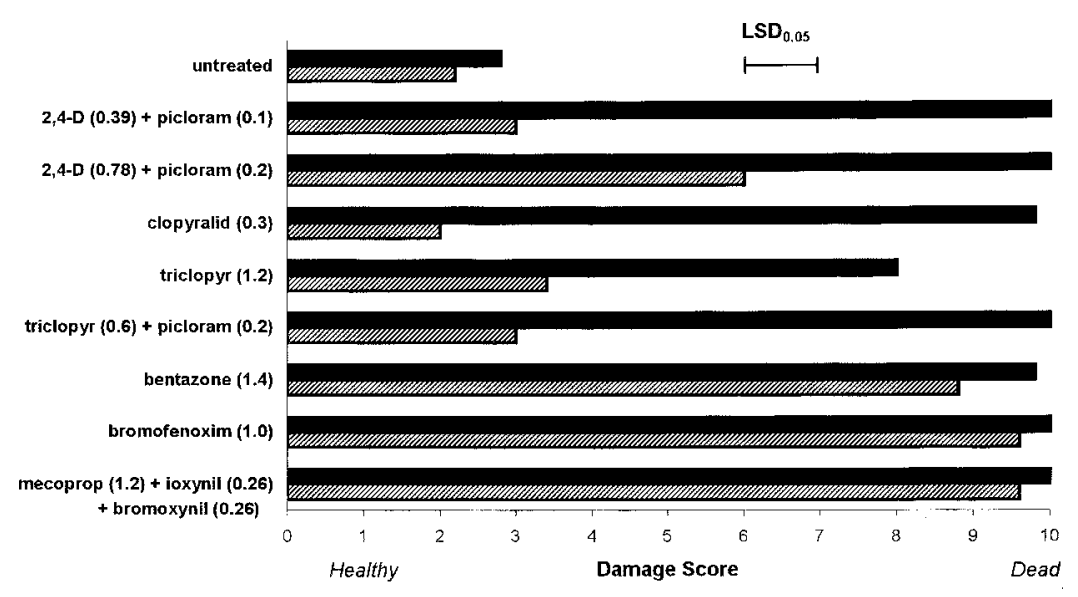

FIGURE 2: Damage caused to Onehunga weed from Helensville (striped bars) and Massey University (solid bar) 6 weeks after herbicide application as assessed by scores $(0=$ healthy, $10=$ dead $)$.

\section{REFERENCES}

Anderson, W.P. 1996: Weed Science - Principles and Applications. $3^{\text {rd }}$ Edition. West, Minneapolis. $388 \mathrm{p}$.

Bourdot, G.W. 1996: The status of herbicide resistance in New Zealand weeds. In: Bourdot, G.W.; Suckling, D.M. ed. Pesticide Resistance - Prevention \& Management. New Zealand Plant Protection Society, Christchurch, New Zealand. Pp. 81-89.

Harrington, K.C.; Hewage, N. 1997: Resistance of slender winged thistle to MCPA. Proc. 50th N.Z. Plant Prot. Conf.: 538.

Heap, I. 2001: International survey of herbicide resistant weeds. www.weedscience.com $(12 / 02 / 01)$

Kutrys, S.; Ciarka, D.; Gawronski, S.W. 1998: Utilisation of negative cross-resistance in control of weeds resistant to herbicides. Proceedings of international seminar on ecological aspects of nutrition and alternatives for herbicides in horticulture. Warszawa, Poland, 10-15 June 1997. Pp. 39-40.

Zanin, G.; Lucchin, M. 1990: Comparative growth and population dynamics of triazineresistant and -susceptible biotypes of Solanum nigrum L. in relation to maize cultivation. J. Genetics \& Breeding 44: 207-216.

APPENDIX: Herbicides and their formulations used in this study. atrazine (Gesaprim 500FW), bentazone (Basagran), bromofenoxim (Faneron), cyanazine (Bladex 50WP), 2,4-D + picloram (Tordon 50-D), dicamba (Banvel 200), MCPB (IWD MCPB), mecoprop + ioxynil + bromoxynil (Axall), methabenzthiazuron (Tribunil), pendimethalin (Stomp 330-E), prometryn (Gesagard 500FW), terbuthylazine (Gardoprim), terbutryn (Igran 500FW), triclopyr + picloram (Tordon Brushkiller). 